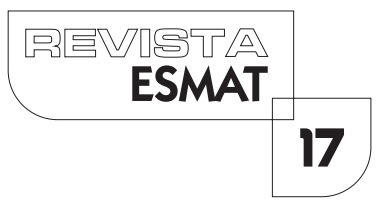

\title{
DA COMPATIBILIDADE ENTRE CELERIDADE E FUNDAMENTAÇÃO DAS DECISÕES
}

\author{
THE COMPATIBILITY BETWEEN celerity AND FOUNDATION OF DECISIONS
}

Luís Gustavo Reis Mundim

Professor da Pós-Graduação em Direito Processual do IEC-PUC/MINAS. Mestre em Direito Processual, pela PUC/MINAS. Pós-Graduado em Direito Processual, pelo Instituto de Educação Continuada, IEC-PUC/MINAS. Bacharel em Direito, pela PUC/MINAS. Advogado e palestrante. E-mail: luis.mundim@reismundim.adv.br

\section{RESUMO}

presente artigo objetiva demonstrar a compatibilidade entre os princípios da fundamentação das decisões e da celeridade. $\bigcirc$ procedimento metodológico utilizado consistiu na revisão bibliográfica acerca dos princípios constitucionais do contraditório e da fundamentação das decisões, bem como da celeridade. A proposta de desenvolver um estudo sobre a compatibilização da fundamentação das decisões com a celeridade teve como motivação a necessidade de fiscalização das partes da atividade jurisdicional sem que o julgador decida solitariamente o direito a partir de seus sentimentos e convicções. A interligação do contraditório com a fundamentação das decisões não permite que o julgador flexibilize a fundamentação em nome da celeridade, por se tratar de uma postura antidemocrática e inconstitucional, o que tem sido realizado pelos tribunais pátrios. Atingido esse objetivo, foi possível analisar que a celeridade e a fundamentação são princípios compatíveis, porque as principais mazelas da morosidade judicial se encontram presentes nas etapas mortas do procedimento e na falta de estrutura do judiciário.

PALAVRA-CHAVE: Celeridade. Fundamentação das Decisões. Contraditório. Processualidade Democrática.

\section{ABSTRACT}

The aim of this article is to demonstrate the compatibility between the principles of the foundation of decisions and celerity. The methodological procedure used consisted of the bibliographical review about the constitutional principles of the contradictory and the reasoning of the decisions, as well as the celerity. The proposal to develop a study on the compatibility of the foundation of decisions with celerity was motivated by the need to supervise the parties to the judicial activity without the judge deciding solitarily the right from their feelings and convictions. The interconnection of the contradictory with the reasoning of decisions does not allow the judge to flexibilize the reasoning in the name of celerity, because it is an antidemocratic and unconstitutional 
position, which has been carried out by the country courts. Once this objective has been reached, it was possible to analyze that celerity and reasoning are compatible principles, hence the main problems of judicial delays are present in the dead stages of the procedure and in the lack of structure of the judiciary.

KEYWORDS: Celerity. Grounds of Decisions. Contradictory. Democratic Processuality.

\section{INTRODUÇÃO}

O presente trabalho possui como temática a análise da compatibilidade entre os princípios da celeridade e da fundamentação das decisões.

Nessa perspectiva, examinou-se na primeira parte do trabalho a noção de fundamentação no Estado Democrático de Direito. Isso porque a fundamentação das decisões deve perpassar pelo princípio do contraditório, uma vez que os argumentos, provas e interpretações fático-jurídicas trazidas pelas partes devem ser consideradas pela decisão, a fim de concretizar participação e fiscalização do conteúdo decisório. Demonstrou-se que a fundamentação das decisões se difere da motivação, visto que esta perpassa, ainda, pelo solipsismo e pelo monopólio decisório do juiz.

Assim, na segunda parte, analisou-se o tratamento normativo dado pelo Código de Processo Civil ao princípio da fundamentação das decisões e ao princípio do contraditório. Analisou-se, portanto, o artigo 489, $\S 1^{\circ}$, e seus incisos, os quais tratam de hipóteses em que será considerada nula determinada decisão por ausência de fundamentação. Reforçou-se, ainda, a articulação entre contraditório e fundamentação pelo Código de Processo Civil, o que trará legitimidade aos pronunciamentos decisórios.

$\mathrm{Na}$ terceira parte, demonstraram-se os riscos e os perigos da flexibilização da fundamentação das decisões em nome do princípio da celeridade. Demonstrou-se que os tribunais pátrios têm esvaziado o conteúdo normativo do artigo 489 do Código de Processo Civil para imprimir velocidade nos julgamentos sem a adequada fundamentação, o que acaba por impedir a participação, influência e controle pelas partes do conteúdo decisório, além de trazer riscos à democracia.

Por fim, na quarta parte, analisou-se que a celeridade é compatível com a fundamentação das decisões, pois existem técnicas procedimentais, a exemplo da decisão de saneamento e organização, que permitem uma adequada participação das partes e fundamentação decisória. Assim, vislumbrou-se que as etapas mortas do procedimento e a falta de estrutura do judiciário são as causas da morosidade judicial, e não a existência de direitos e garantias processuais fundamentais.

Certamente não se pretendeu esgotar a temática, mas espera-se que o presente trabalho dê uma reflexão crítica sobre o tema. 


\section{A FUNDAMENTAÇÃO DAS DECISÕES NO ESTADO DEMOCRÁTICO DE DIREITO}

No Estado Democrático de Direito, a função jurisdicional passa a ter um duplo aspecto, qual seja, atividade-dever a ser exercida pelo Estado e direito fundamental. (BRÊTAS, 20 I5). Nessa esteira, a jurisdição passa a ser limitada e balizada pelo processo constitucional, regido e constituído pelos princípios do contraditório, ampla defesa e isonomia, o que afasta com o entendimento da dogmática tradicional de que o processo é um instrumento a serviço da jurisdição (LEAL, 20 I 6a).

O processo, como instituição jurídico-constitucionalizada regente e balizadora dos procedimentos administrativos, legislativos e jurisdicionais, torna-se direito-garantia acessível a todos do povo - sujeito constitucional -, para o exercício de participação e controle dos atos decisórios estatais. Ou seja, os provimentos jurisdicionais passam a ser "decorrentes do compartilhamento dialógico-processual entre cidadão e Estado, a se permitir a criação, alteração, reconhecimento, aplicação e extinção de direitos" (MUNDIM, 20।8, p. 65-66).

Assim, se a jurisdição somente é exercida mediante a limitação do devido processo constitucional, "fundamentar a decisão jurisdicional é justificar o órgão estatal julgador, no processo, as razões pelas quais a decisão foi proferida" (BRÊTAS, 20 I 5 , p. 169). Vale dizer, então, que a justificação a ser exercida pelo juízo não pode ser advinda do solipsismo do julgador, de sua discricionariedade ou de seu livre convencimento, em razão do devido processo e pelo fato de que "o julgador não está sozinho no processo, não é seu centro de gravidade e não possui o monopólio do saber" (BRÊTAS, 2015, p. 170).

É o que leciona Vinicius Lott Thibau:

Por conquistas teóricas obtidas pela Ciência do Direito Processual, é possível afirmar que, na atualidade, a racionalidade da decisão não decorre da qualidade pessoal do juiz que, de modo solipsista e imperturbável, impõe-se como capaz de bem estabelecer o destino jurídico do povo mediante análise diferenciada do direito e do resultado probatório.

Na contemporaneidade, a racionalidade decisória não é extraída da consciência do julgador, mas da estrutura técnica que, regida pelos princípios institutivos do processo, erige-se como espaço de plena discursividade preparatória de uma decisão que se desgarra de seu redator no momento em que aborda todas as questões fático-jurídicas debatidas no procedimento. (THIBAU, 20I5, p. 6I).

Em observância a tal diretriz, a Constituição, de 1988, estabelece normativamente o princípio da fundamentação das decisões em seu artigo 93, inciso IX, o qual 
dispõe que todas as decisões proferidas pelos órgãos jurisdicionais serão fundamentadas.

Para se ter uma adequada fundamentação voltada à constitucionalidade democrática, esta deve manter "uma co-dependência com o princípio do contraditório, de modo a ensejar que os sujeitos processuais possam influenciar com seus argumentos e provas a construção participada dos fundamentos da decisão" (SOUSA, 20।8, p. 73).

O princípio do contraditório, então, é o "propiciador da participação do povo na construção das decisões estatais, pois permite que os argumentos das partes sejam considerados no momento em que for prolatada a decisão" (ALVES; MUNDIM, 2018, p. 72).

contraditório irá permitir às partes "o exercício constante da fala, da argumentação e da discursividade” (MUNDIM, 20।8, p. 22I), de modo que a interpretação dos fatos, do direito e das provas, enunciada pelas partes, sejam determinantes para o resultado decisório.

André Cordeiro Leal leciona no mesmo sentido:

É exatamente o contraditório que vai proporcionar, quanto às oportunidades de pronunciamento, uma atuação equitativa dos partícipes nos procedimentos judiciais. Vai também garantir, em conexão com o princípio (requisito) da fundamentação das decisões jurisdicionais, que a decisão se fundamente no Direito debatido pelas partes e nos fatos por elas reconstruídos. (LEAL, 2002, p. 77).

Dierle Nunes (2007) explica que o princípio do contraditório não pode ser mais lido como mera bilateralidade em audiência, de modo estático e formal, deve ser compreendido como uma garantia de influência, e não surpresa com aplicação dinâmica. O contraditório passa a ser compreendido como "cânone essencial de todo o iter procedimental formador do provimento possibilitando uma constante participação dos interessados ao desenvolver do procedimento, impondo instrumentos adequados para o seu exercício concreto, de modo a permitir o diálogo entre os sujeitos processuais" (NUNES, 2007 p. 157).

A partir de tal compreensão e do estudo do processo constitucional, Ronaldo Brêtas expõe que o contraditório possui uma estrutura quadrinômica, formada pelos elementos da informação-reação-diálogo-influência, que deverá ser observada por toda dinâmica procedimental (BRÊTAS, 20 I5, p. 132-133). É por essa estrutura que haverá a comunicação às partes dos atos procedimentais, a fim de que estas possam se manifestar, dialogar e, por fim, ver seus argumentos e provas considerados no julgamento final (BRÊTAS, 20I5).

Por esse aspecto, a sistemática do contraditório acaba por vedar a denominada decisão-surpresa "fruto do mero convencimento solitário do juiz, sem debate prévio 
com as partes" (BRÊTAS, 20 I5, p. 128). Torna-se defeso, portanto, decisões às quais "os magistrados trazem fundamentos de fato e de direito alheios ao conjunto argumentativo e probatório constante do processo" (MUNDIM, 2018, p. 144).

Nessa esteira, o pronunciamento final deve ser resultante lógico da atividade procedimental realizada em torno das questões fático-jurídicas, das provas e dos argumentos debatidos, em contraditório, pelas partes (MUNDIM, 20I8, p. 225). Somente assim é que se poderá verificar a legitimidade das decisões, pois, caso contrário, a decisão estará eivada de inconstitucionalidade (BRÊTAS, 20 I 5, p. 178).

Portanto, importante trazer à baila o que leciona Flaviane de Magalhães Barros, que ressalta a importância da conexão entre contraditório e a fundamentação das decisões:

[...] a fundamentação é indissociável do contraditório, visto que garantir a participação dos afetados na construção do provimento, base da compreensão do contraditório, só será plenamente garantida se a referida decisão apresentar em sua fundamentação a argumentação dos respectivos afetados, que podem, justamente pela fundamentação, fiscalizar o respeito ao contraditório e garantir a aceitabilidade racional da decisão. (BARROS, 2008, p. 135).

Por fim, importante diferenciar a motivação das decisões da fundamentação. A motivação consiste no apontamento, pelo juiz, dos elementos que ele, individual e solitariamente, considerou relevantes para o julgamento da lide "e que fizeram que ele tomasse tal decisão em determinado sentido - e não em outro" (THEODORO JÚNIOR; NUNES; PEDRON; BAHIA, 2016, p. 333-334).

Nesse sentido, motivar é elaborar a decisão a partir dos sentimentos, convicções e sensibilidade do julgador, que irá "manejar os jogos de linguagem procedimental", a fim de que a decisão se ajuste "ao ordenamento jurídico, para, de modo reflexo ou irreflexo, ser considerada proferida formalmente conforme a lei" (LEAL, 20 I6b, p. 92).

Logo, a motivação é o ajustamento da decisão solipsista e pessoal do julgador aos influxos da lei, a fim de dar caráter de legalidade ao pronunciamento decisório, o que acaba por vedar qualquer fiscalidade. É o que explica André Cordeiro Leal:

Motivar, como se infere dos inúmeros escritos que tratam da atividade decisória, seja ela 'jurisdicional', seja legislativa, reduz-se, na dogmática jurídica brasileira atual (ainda impregnada de ancianidade inaceitável decorrente da desconsideração dos debates filosóficos sobre a temática), a um esforço retórico 
que intenta obter adesão do destinatário normativo através da sedução gerada por uma racionalidade estratégica (instrumental) engendrada para obstar o questionamento e a interlocução crítica que poderia ser suscitada pelo destinatário normativo, de forma a que, luhmanianamente, os destinatários das decisões estejam permanentemente aptos a aceitar decisões jurídicas de conteúdo ainda não definido. (LEAL, 20 I2, p. 381$)$.

Portanto, na processualidade democrática, a fundamentação das decisões está vinculada "ao espaço técnico-procedimental-discursivo do processo cognitivo de direitos, como conclusão co-extensiva da argumentação das partes" (LEAL, 20 I6b, p. 23), o que irá gerar controle e legitimidade decisória por permitir que estas sejam autoras e coautoras do pronunciamento decisório.

\section{A FUNDAMENTAÇÃO DAS DECISÕES NO CÓDIGO DE PROCESSO Cl- VIL: O ARTIGO No 489}

Atento ao modelo constitucional de processo, o Código de Processo Civil traz um capítulo destinado às normas fundamentais do processo, premissas interpretativas de todo o código, as quais devem nortear a interpretação de quaisquer dispositivos, em unicidade e sistematicidade (THEODORO JÚNIOR; NUNES; PEDRON; BAHIA, 2016, p. 20).

Dentre as normas fundamentais, o Código de Processo Civil traz a previsão normativa do contraditório como garantia de influência, e não surpresa, nos artigos $7^{\circ}$, $9^{\circ}$ e 10, que determinam a observância do referido princípio pelo juiz, além da vedação expressa às decisões-surpresa.

Alinhado ao princípio do contraditório, há, ainda, a previsão acerca da fundamentação das decisões, especificamente no artigo I I, o qual dispõe que as decisões deverão ser fundamentadas sob pena de nulidade. Importante destacar o artigo 489, que, apesar de não estar inserido especificamente no capítulo das normas fundamentais, trata de norma de observância obrigatória pelos juízes e tribunais, além de ser norteador de todos os pronunciamentos decisórios, o que traz seu caráter de norma fundamental.

Nesse sentido, em técnica não muito habitual, o Código de Processo Civil, na redação do art. 489, $\S 1^{\circ}$, "descreve situações nas quais se evidenciam decisões mal fundamentadas, costumeiramente verificadas na malsinada prática forense, um costume vicioso já enraizado nos juízos e Tribunais brasileiros" (BRÊTAS et al., 20 I6, p. 59) que impediam que a influência no resultado do processo fosse concretizada.

Assim, o artigo 489, $\S 1^{\circ}$, "propõe-se a elencar, mediante um critério negativo, de exclusão - isto é, do que não se considera uma decisão fundamentada - hipóte- 
ses a serem observadas quando da prolação de um ato decisório" (SOUSA, 20 I8, p. 84).

Há de se observar que tal diretriz não é direcionada apenas às sentenças, mas também às decisões interlocutórias, acórdãos e decisões monocráticas, além de que as hipóteses de ausência de fundamentação constantes nos incisos do $\S 1^{\circ}$ do artigo 489 são meramente exemplificativas, e não taxativas (MAGALHÃES, 2018, p. 4748).

Nesse sentido, o artigo 489, $\S 1^{\circ}$, inciso I, veda que decisões se limitem a indicar, reproduzir ou parafrasear ato normativo, sem explicação acerca de sua relação com a lide ou questão decidida. Conforme nos explica Lorena Ribeiro de Carvalho Sousa (20।8, p. 86), é necessário que haja a contextualização ao caso da aplicação do ato normativo, a partir do debate realizado pelas partes em contraditório, com a consideração dos argumentos e provas produzidos durante o itinerário procedimental. Ou seja, "a decisão não pode ser resumida a uma aplicação mecanizada, sob pena de traduzir uma reprodução exegética no ato de decidir" (SOUSA, 20 I 8, p. 86).

Por sua vez, o inciso II dispõe que é defeso o emprego de conceitos jurídicos indeterminados sem a explicação do motivo concreto de sua incidência no caso. Assim, o julgador não poderá escolher quais argumentos subjetivistas irá se valer para preencher o sentido normativo de um conceito indeterminado, o que mascara a fundamentação e se pauta na discricionariedade do intérprete (SOUSA, 20 I 8, p. 87).

Conforme expõem Humberto Theodoro Jr., Dierle Nunes, Flávio Pedron e Alexandre Bahia (2016, p. 354), o artigo 489, § 10, inciso II, do Código de Processo Civil "exige do juiz o esclarecimento do sentido que pretende conferir aos conceitos jurídicos indeterminados, permitindo, assim, que as partes possam identificar seus preconceitos e pressupostos, trazendo-os à lume no debate processual".

O inciso III, por seu turno, veda que a decisão invoque motivos que se prestariam a justificar qualquer outra decisão, ou seja, evita-se "que decisões padronizadas - manipuláveis com um simples 'copiar e colar'” (SOUSA, 20 I 8, p. 88)-sejam proferidas a todo o momento pelos julgadores. Ademais, evitam-se decisões citra, ultra e extra petita, as quais se utilizam de fundamentos distintos do objeto do processo.

O inciso IV, em nítida e acertada articulação ao princípio do contraditório, prevê que a decisão será considerada nula quando não enfrentar todos os argumentos deduzidos no processo capazes de, em tese, infirmar a conclusão adotada pelo julgador. A locução "em tese" é uma falha na redação do referido artigo já que abre margem para a discricionariedade do julgador, conforme se mostrará no próximo tópico.

Por fim, os incisos V e VI estão voltados à aplicação e distinção de precedentes, enunciados de súmula e jurisprudência pelos julgadores. No inciso $V$, as decisões que se limitam a invocar tais padrões decisórios, sem a identificação de seus fundamentos determinantes, tampouco a demonstração da similitude fático-jurídica com a lide, são nulas, porque não pode o julgador aplicá-los como se fossem teses gerais e abstratas. Isso porque "a construção e aplicação dos precedentes na processualidade 
democrática somente será constitucionalmente legitimável se balizadas pelo devido processo legal como regente de um processo de conhecimento articulado por direitos fundamentais" (MUNDIM, 20।8, p. 25I).

Já no tocante ao inciso $\mathrm{Vl}$, não é possível que o magistrado deixe de seguir enunciado de súmula, jurisprudência ou precedente invocado pela parte sem demonstrar a distinção da lide ou a superação do entendimento. Ora, a distinção e a superação de precedentes são técnicas que irão possibilitar "o afastamento de um precedente inadequado à lide sob julgamento, com a criação de um amplo espaço processual de argumentação entre todos os sujeitos processuais" (MUNDIM, 2018, p. 129-130). Assim, a não observância da distinção e da superação pelos magistrados não pode ser relegada a segundo plano, "sob pena de não se ter uma adequada apreciação e afastamento do precedente à lide em debate, o que acarretará perda de legitimidade na decisão final" (MUNDIM, 20 I8, p. I30).

Desta feita, a proposta contida no artigo 489, $\S 1^{\circ}$, do Código de Processo Civil, pode ser sintetizada, como lecionam Ronaldo Brêtas e outros:

A tanto, em síntese, os juízes, em seus pronunciamentos decisórios, deverão observar as seguintes recomendações do Estado que os nomeou: $1^{a}$.) - enunciar explicitamente os fundamentos pelos quais os argumentos das partes não poderão ser acolhidos; $2^{a}$.) - promover o acertamento das suas alegações de fato; $3^{a}$.) - individualizar justificadamente as normas do ordenamento jurídico adequadas à solução do caso concreto; $4^{a}$.) - apontar, na decisão proferida, claramente, as consequências da qualificação jurídica dos fatos valorados pelas provas; $5^{a}$.) - realizar cotejo analítico dos excertos dos precedentes e das súmulas jurisprudenciais invocados no julgamento, a título de orientação decisória, com as questões de fato e de direito discutidas, analisadas e decididas no processo; $6^{a}$.) - afastar em definitivo os males do solipsismo, da discricionariedade e do arbítrio no ato de julgar, quando prestam a atividade jurisdicional monopolizada pelo Estado. (BRÊTAS et al, 2016, p. 60-6l).

Acresce-se, ainda, o artigo 298 do Código de Processo Civil, que determina a observância dos requisitos de inteligência das decisões quando proferida em sede de tutela provisória, também aplicável às sentenças, acórdãos e decisões monocráticas em razão da unicidade deste Código. Os requisitos de inteligência consistem na precisão e clareza. Conforme explica Armando Ghedini Neto, clara é uma decisão compreensível que não possui dificuldades de ser entendida e insuscetível de interpretações ambíguas, enquanto a precisão se refere à certeza e à delimitação, pois o "pronunciamento decisório deve trazer certeza, na medida em que nele são resolvidas as controvérsias, devendo ficar nitidamente delimitados os direitos e obrigações 
correlatas, não podendo haver dúvida. A precisão se refere aos limites do pedido" (GHEDINI NETO, 20I5, p. 262).

Portanto, o que se verifica a partir de tais dispositivos do Código de Processo Civil, é a sua aproximação com uma perspectiva constitucional-democrática do processo, já que o magistrado não pode ser mais considerado como mero repetidor de atos normativos, súmulas, ementas, precedentes, "mas, ao revés, deve, atentamente, levar em consideração a argumentação desenvolvida pelas partes, dentro do ambiente dialógico procedimental", porque se exige o enfrentamento de todos os argumentos e provas trazidos pelas partes, "a fim de permitir maior controlabilidade de suas justificativas, sob pena de se restar caracterizada violação ao princípio do contraditório e à fundamentação das decisões" (SOUSA, 20 I 8, p. 100).

Entretanto, o princípio da fundamentação das decisões tem sido perigosamente mitigado por juízes, sob a justificativa de que analisar todos os argumentos e provas trazidos pelas partes é incompatível com a celeridade, a duração razoável dos procedimentos e a efetividade. Conforme se verá, o afastamento da fundamentação das decisões em prol da celeridade cria um ambiente antidemocrático com riscos à processualidade democrática.

\section{OS PERIGOS DA FLEXIBILIZAÇÃO DA FUNDAMENTAÇÃO DAS DECI- SÕES EM PROL DA CELERIDADE}

Em 2004, houve a introdução do princípio da duração razoável do processo pela Emenda Constitucional n 45 no ordenamento pátrio, ocasião em que a busca por uma jurisdição-relâmpago e instantânea se tornou moda entre os operadores do direito que "apregoam os permanentes objetivos de conferir celeridade à tramitação dos processos e de evitar a morosidade da atividade jurisdicional do Estado, conferindo-Ihe racionalidade e eficiência" (BRÊTAS, 2009, p. 457).

Apontam os juristas que a morosidade no trâmite procedimental afeta a efetivação do direito material e que os juízes conduziriam valores para a extração dos "dados da situação de direito material necessários à solução do litigio, entregando a tutela jurisdicional ao vencedor o mais rápido possível” (BEDAQUE, 2010, p. 1 12).

Essa defesa instrumental da duração razoável do processo, alinhada à celeridade e à efetividade, levam à dogmática tradicional a defender "a maleabilização ou a supressão de técnicas processuais como milagrosas fórmulas de ganho de celeridade" (CARVALHO, 2018, p. 160).

Dentro dessas premissas, quando da sanção do Código de Processo Civil, a Associação dos Juízes Federais do Brasil (AJUFE), Associação dos Magistrados Brasileiros (AMB) e Associação Nacional dos Magistrados da Justiça do Trabalho (ANAMATRA) encaminharam à Presidência da República pedidos de veto ao artigo 489, sob a justificativa de que este traria danos à duração dos processos e à produção das decisões, o que felizmente não ocorreu. 
Diante da ausência de veto ao artigo 489, a Escola Nacional de Formação e Aperfeiçoamento de Magistrados (ENFAM) aprovou diversos enunciados que flexibilizaram o contraditório como garantia de influência, e não surpresa, e consequentemente a fundamentação das decisões. Podem-se mencionar, como exemplos, o Enunciado 01, o qual dispõe que "Entende-se por 'fundamento' referido no art. 10 do CPC/20 I 5 o substrato fático que orienta o pedido, e não o enquadramento jurídico atribuído pelas partes", e o Enunciado 06, em que "Não constitui julgamento surpresa o lastreado em fundamentos jurídicos, ainda que diversos dos apresentados pelas partes, desde que embasados em provas submetida ao contraditório".

O Tribunal de Justiça de Minas Gerais, ao elaborar enunciados interpretativos do Código de Processo Civil, consignou no Enunciado n 07 que "considera-se suficientemente fundamentada a decisão em que o juiz se manifesta sobre os argumentos relevantes e pertinentes alegados pelas partes".

Essa postura já fez com que o Superior Tribunal de Justiça, em total agressão ao modelo constitucional de processo, esvaziasse o conteúdo do artigo 489 do Código de Processo Civil, a fim de adequá-lo, equivocada e inconstitucionalmente, ao entendimento de que o juiz não está obrigado a fundamentar e analisar os argumentos das partes. É o que ocorreu no julgamento do Mandado de Segurança no 21.3 I 5/DF, de relatoria da ministra Diva Malerbi (desembargadora convocada do TRF $3^{\text {a }}$ Região), em 15/6/2016, vejamos:

[...] ○ julgador não está obrigado a responder a todas as questões suscitadas pelas partes, quando já tenha encontrado motivo suficiente para proferir a decisão. A prescrição trazida pelo art. 489 do CPC/20I 5 veio confirmar a jurisprudência já sedimentada pelo Colendo Superior Tribunal de Justiça, sendo dever do julgador apenas enfrentar as questões capazes de infirmar a conclusão adotada na decisão recorrida. (BRASIL, 2016).

O que se percebe é que, diante de uma sociedade voltada ao desempenho desenfreado - que se torna cansada (HAN, 20 17) -, o princípio da celeridade é elevado a um status que busca tão somente uma eficiência (instrumental) de resultados quantitativos sem preocupação com a qualidade e com a legitimidade das decisões (NUNES; TEIXEIRA, 20I3).

Nessa esteira, a implementação de direitos e garantias fundamentais é relegada à efetividade-utilidade das decisões, o que viola o contraditório, a ampla defesa e a isonomia, bases instituintes do processo constitucional-democrático.

O princípio da fundamentação das decisões torna-se, então, mero formalismo, em que o magistrado expõe subjetivamente sua motivação ignorando os argumentos e provas trazidos pelas partes durante o iter procedimental. Essa prática abre margem às decisões anacrônicas, solipsistas e discricionárias de que "o juiz não está obrigado a responder ao questionário das partes" ou "o juiz não está obrigado a analisar todos 
os argumentos suscitados pelas partes". E por preconizar a fundamentação como mero formalismo, o juiz estaria apto a afastá-la com a finalidade de consecução dos escopos metajurídicos, a exemplo do que preconiza José Roberto Bedaque (20 l0), forte na concepção instrumentalista de processo.

Sob essa perspectiva, acaba-se por "privilegiar o princípio da celeridade processual, em detrimento do princípio do devido processo legal (contraditório e ampla defesa, em particular)", pois "no afã de se chegar a uma decisão o tanto quanto mais rápido possível são 'atropeladas' muitas faces do processo" (MAGALHÃES, 20। 8, p. 45).

A celeridade, portanto, acaba por esvaziar o conteúdo da fundamentação e transmutá-lo em motivação, conforme leciona Joseli Lima Magalhães:

Premidos muitas vezes em decidir a todo momento, não por menos para apresentarem relatórios, os quais irão enlourá-los para futuras promoções (em contagem de pontos, em tabelas promocionais), como que a quantidade seja mais significativa que a qualidade, os magistrados utilizam-se de frases já pré-elaboradas, standarts, jargões jurídicos, para tentar aplicar a lei ao caso concreto. A fundamentação encontra-se somente na cabeça do juiz, no seu intelecto, ou melhor, no que pensa ser intelecto, deixando as partes sem condições técnicas, inclusive, de saber por que decidiu daquela ou desta forma. É uma autocracia reinante, onde a subjetividade é marca indelével ou da falta de compromisso com o exercício da profissão ou mesmo, muitas vezes, é puro despreparo de técnica e preguiça mental. (MAGALHÃES, 2018 , p. 49).

Para piorar a situação, o já mencionado deslize cometido na redação do artigo $489, \S 1^{\circ}$, inciso IV, no que tange à locução "em tese", permite que o magistrado alegue que não enfrentou determinado argumento ou prova da parte por não infirmar a sua conclusão. (THEODORO JÚNIOR, NUNES, BAHIA, PEDRON, 2015, p. 355 ).

O inciso IV é claro ao dispor que a decisão que não considerar os argumentos das partes será nula, "razão pela qual o magistrado, se entender ser o caso, deverá também mostrar que seu entendimento resiste a qualquer outro argumento constante dos autos" (THEODORO JÚNIOR, NUNES, BAHIA, PEDRON, 2016, p. 355), e não simplesmente deixar de analisar o conjunto argumentativo-probatório levantado pelas partes. Essa interpretação deve ser derivada a partir da principiologia fundamental estruturada na Constituição e no Código de Processo Civil, a exemplo do contraditório e da ampla defesa.

A manutenção dessa realidade hostil, de ausência de fundamentação e de análise dos argumentos e provas trazidos pelas partes, faz com que a interpretação, a aplicação e a construção do direito sejam "depositadas solitariamente nas mãos dos juízes, 
que - como entes paternos - se veem autorizados a educar os cidadãos a seu modo, construindo o direito por si próprios" (CARVALHO, 20। 8, p. I 53).

A negativa de fundamentação em prol da celeridade é perigosa, pois: gera déficit de legitimidade e democraticidade do processo; não permite a participação e influência das partes no resultado decisório; impossibilita que as partes exerçam controle e fiscalizem a atividade jurisdicional; olvida a efetivação de direitos e garantias fundamentais; gera um espaço de suspensão e exceção da legalidade; fere o contraditório e a ampla defesa já que os conteúdos de tais princípios serão ignorados pelo magistrado; aumenta a discricionariedade e subjetividade do julgador; fere a imparcialidade; possibilita o aumento do número de decisões declaradas nulas por recursos interpostos, dentre inúmeros outros retrocessos que serão causados à democracia.

Interessante notar, também, a busca por atalhos cognitivos (heurística) para se confirmar vieses anteriores, a fim de dar rápida solução ao litígio. Conforme expõem Dierle Nunes, Natanael Lud Santos e Flávio Pedron (2018, p. 37), os vieses de cognição "geram erros sistemáticos de tomada decisão" já que expõem as subjetividades do julgador e perpetuam a "análise viciada da argumentação jurídica e dos elementos de prova".

Vale dizer, ainda, que essa visão de produção de decisões a todo custo (neoliberal) faz com que o juiz tenha "uma visão tutelar ou clientelista do jurisdicionado", que desmobiliza e induz o "sujeito à aceitação da inevitabilidade de suas circunstâncias como um acidente quase-natural (fatalismo)" (NUNES; TEIXEIRA, 20I3, p. 147). Ou seja, "o cidadão é transformado, assim, em objeto do poder" (NUNES; TEIXEIRA, 20 I3, p. 147).

Além disso, conforme expõem Dierle Nunes e Ludmila Teixeira (20 I3, p. 147), essa ótica de busca de resultados também transforma "o juiz em alvo de uma violência estrutural, veiculada pela extorsão de seu consentimento em cooperar com um projeto que dificilmente subscreveria voluntariamente e se parasse para romper e refletir criticamente com o horizonte paradigmático imposto".

Portanto, a celeridade, vista em uma perspectiva instrumental-utilitarista, somente traz prejuízos ao processo e à democracia, porque reduz todo direito e toda garantia fundamentais já assegurados no plano constitucional a todos da Comunidade Jurídico-Política (povo). Importante, pois, a crítica de Rosemiro Pereira Leal à uma perspectiva de eficiência meramente quantitativa:

Não se trata do parâmetro econômico-financeiro do custobenefício. No Estado Democrático de Direito, não há cogitar resultados financeiros e econômicos pelo encurtamento da atividade processual ou na rapidez (celeridade) dos procedimentos para otimização dos custos do serviço público ou do pronto atendimento dos pleitos judiciais, pois a única vantagem buscada pela lei processual é assegurar, de modo irrestrito, o direito-garantia da ampla defesa, contraditório e isonomia. (LEAL, 2016a, p. 187). 
Assim, conforme se demonstrará a seguir, a celeridade é compatível com a fundamentação das decisões, razão pela qual é possível fundamentar adequadamente no Código de Processo Civil sem prejuízos significativos à legitimidade decisória.

\section{DA COMPATIBILIDADE ENTRE FUNDAMENTAÇÃO DAS DECISÕES E CELERIDADE}

Ao contrário do que preconizam os defensores da celeridade em prol da fundamentação, tais princípios são compatíveis entre si e, na democracia, se harmonizam para o alcance da legitimidade, porque os problemas da morosidade judicial não se encontram apenas na legislação.

Nesse sentido, há de se diferenciar duração razoável do procedimento, celeridade e efetividade, uma vez que o sincretismo semântico ideologizado pelos instrumentalistas desvirtua as diferenças entre as noções de tais princípios, além de esvaziar os conteúdos da legalidade e da processualidade.

$\mathrm{Na}$ perspectiva do direito processual democrático, a celeridade deve ser compreendida e interligada ao "cumprimento do princípio da legalidade e do respeito aos princípios da isonomia, da ampla defesa e do contraditório" sem que ocorram quaisquer supressões ou reduções de tais princípios que deverão ser exercidos por todos os sujeitos processuais, além da "observância necessária pelo próprio Estado-Juiz e pelos auxiliares do juízo" (TAVARES, 2010 , p. I |4). Assim, "a celeridade consiste no cumprimento dos prazos previstos no conjunto de procedimentos legais (devido processo legal)" (MUNDIM, 20।8, p. 173).

Já a duração razoável do processo como a "adequação temporal da jurisdição, mediante processo sem dilações indevidas" (BRÊTAS, 20 I 5, p.209), ou seja, consiste no percurso procedimental dentro dos marcos temporais previstos legalmente.

Nessa esteira, importante dizer que não é a fundamentação que irá delongar a duração do procedimento, porque não é o principal problema da morosidade. $\bigcirc$ que se deve combater são as denominadas etapas mortas do procedimento, resultantes de longos períodos de paralisia sem que quaisquer atos sejam praticados ou realizados fora do tempo legal em que deveriam ter sido cumpridos (BRÊTAS, 20 I5, p. 213$)$.

O entendimento contrário acaba por mascarar "as próprias falhas estruturais presentes na função jurisdicional pela imposição da ideia de que o processo é lento e moroso na aplicação e satisfação do direito das partes" (MUNDIM, 20 I 8, p. 174). É o que expõe a pertinente crítica de João Carlos Salles de Carvalho:

Esses discursos de efetividade, uma vez desmascarados, mostram-se repletos de opacas promessas, já que pouco ou nada falam sobre as 'etapas mortas' do processo, sobre os paradoxais prazos impróprios, sobre o excesso de férias e a obsoleta rotina de expediente forense, sobre as decisões sendo confeccionadas por estagiários dentro dos gabinetes, 
sobre metas simbólicas ou inalcançáveis, sobre o notável desestímulo de alguns servidores, sobre o corporativismo protecionista da magistratura, sem aqui citar tantos outros embaraços administrativos que sabidamente permeiam a prática jurídica, mas que - por receio ou por tabu - tornaramse assunto praticamente intocável nos meios acadêmico e forense. (CARVALHO, 2018, p. 165).

Já a efetividade não pode ser "oferecida como um bem de consumo numa decisão judicial, mas deve significar o ganho de legitimidade que passa pela institucionalização do devido processo" (MUNDIM, 2018, p. 174). A efetividade, portanto, deve perpassar por uma eficiência não só quantitativa, mas também qualitativa, porque geradora de eficiência sistêmica, a partir dos princípios do contraditório, ampla defesa e isonomia, como expõe Rosemiro Pereira Leal:

$\bigcirc$ que se quer dizer é que o âmbito da efetividadeceleridade do direito é, na teoria da executividade em feições democráticas, só aferível pela eficiência sistêmica das garantias dos direitos de vida-contraditório, dignidade-isonomia e liberdade-ampla defesa que são os fundamentos de um modelo de sociedade a ser processualmente construída e não uma sociedade contextualmente encontrada, aguardada (pretendida, exortada) ou achada substantivamente pelo homem. (LEAL, 20 I3, p. 94).

que ainda não foi observado pela magistratura é a utilização de técnicas procedimentais que irão compatibilizar a fundamentação das decisões com a celeridade procedimental.

Como uma das mais importantes técnicas, há de se mencionar a decisão de saneamento e organização do procedimento, prevista no artigo 357 do Código de Processo Civil. Nessa decisão, que se estrutura de modo bipartite, além de corrigidos eventuais vícios ou nulidades processuais (saneamento), serão delimitadas as questões de fato e de direito, a atividade probatória a ser realizada, e definido o ônus da prova (organização).

Nesse diapasão, a decisão de saneamento e organização servirá como itinerário e como filtro para as questões a serem analisadas pelos magistrados, a teor do artigo 489, $\S 1^{\circ}$, inciso IV, do Código de Processo Civil, conforme nos ensina Alexandre Varela de Oliveira:

É sob esta ótica que se ressalta a relevância da técnica de saneamento e organização, prevista no art. 357 do CPC/20 I 5 , na medida em que atua como um verdadeiro filtro para a aplicabilidade do inciso IV, $\S 1^{\circ}$ do art. 489, construindo um itinerário para a formação do pronunciamento jurisdicional decisório, por intermédio de um debate profícuo entre os 
sujeitos processuais, delimitando, de forma comparticipada, as questões objeto da cognição a serem exercidas nas demais fases lógicas procedimentais. (VARELA, 2018, p. I| 2).

Isso porque, nas decisões não se julgam argumentos, mas sim questões de fato e de direito, razão pela qual o inciso IV do artigo 489, $\S 1^{\circ}$, deve ser interpretado a partir de tal delineamento. Essa é a explicação de Alexandre Varela de Oliveira, com base nos ensinamentos de Ronaldo Brêtas:

No entanto, ao se realizar interpretação atrelada às premissas do processo constitucional, deve-se compreender que a expressão 'argumentos deduzidos no processo', empregada no inciso IV, § ${ }^{\circ}$ do art. 489 do CPC/20 I 5, não pode ser confundida com questão, ao passo que os argumentos inferidos no curso do procedimento se encontram vinculados aos pontos controvertidos, os quais despontam como objeto de debate entre as partes para a formação do pronunciamento jurisdicional decisório. Assim, com esteio nos ensinamentos de Ronaldo Brêtas de Carvalho Dias, importante se faz ressaltar que o magistrado não julga argumentos, mas, sim, questões, denotandose, desse modo, uma possível atecnia na redação do referido dispositivo normativo, na medida em que, nesta perspectiva, o julgador não está obrigado a enfrentar todos os argumentos desenvolvidos pelas partes, mas, apenas, as questões de fato e de direito previamente estabelecidas, sendo essa a interpretação mais adequada para o entendimento da norma. (VARELA, 20 I8, p. I I I).

Portanto, há de se perceber que o julgamento das questões de fato e de direito irão permitir a adequada conexão entre contraditório e fundamentação das decisões, já que se evitará o pronunciamento de uma decisão-surpresa, além de que os argumentos e provas deduzidos pelas partes durante o procedimento serão consideradas no julgamento das questões fático-jurídicas.

Nesse sentido, a observância da decisão de saneamento e da organização do processo "deve ser considerada como uma técnica processual para a adequada fundamentação das decisões, sendo impostergável a sua interpretação a partir da cooperação e do contraditório como garantia de influência, e não surpresa" (ALVES; MUNDIM, 20।8, p. 78), a qual irá permitir, também, a adequada harmonização entre celeridade e fundamentação.

Nessa esteira, não se mostra possível afastar a fundamentação das decisões em prol da celeridade, como os tribunais pátrios e a magistratura nacional têm feito, porque se trata de princípios compatíveis, que, a partir da observância de técnicas procedimentais, se harmonizam na busca pela legitimidade e efetividade sistêmica. 
Ressaltem-se, as etapas mortas e a ausência de estrutura adequada é que são as mazelas para a morosidade, e não a existência de direitos e garantias fundamentais asseguradas desde o plano instituinte de formação do direito.

Vale dizer que, na processualidade democrática, a fundamentação permite o devido exercício de fiscalidade pelas partes, além de efetivar o exercício da metalinguagem, já que esta possibilita a arguição, testificação e argumentação críticas dos fundamentos decisórios (ALMEIDA, 2012, p. 176). Assim, somente pela conexão entre contraditório e fundamentação das decisões é que o pronunciamento decisório estará "vinculado e adstrito ao conjunto fático-probatório e aos sentidos dados pelas partes à legislação" (MUNDIM, 20 I 8, p. |46), não sendo possível o afastamento de tais garantias em nome de uma pretensa celeridade.

Nessa esteira, o processo torna-se instituição constitucional de controle da atividade jurisdicional, a partir de sua principiologia, a se permitir a "autoinclusão de todos na construção, aplicação e extinção de direitos fundamentais constitucionalmente assegurados" (MUNDIM, 2018, p. 217).

Logo, celeridade e fundamentação tornam-se compatíveis desde que observado o contraditório, a ampla defesa e a isonomia na busca por legitimidade democrática, e não pela busca incessante de resultados quantitativos.

\section{CONCLUSÃO}

No Estado Democrático de Direito, a atividade jurisdicional torna-se direito de fundamentação e atividade-dever do Estado, motivo pelo qual o povo deve exercer fiscalidade de tal atividade pelo processo. Nesse sentido, a fundamentação das decisões torna-se garantia constitucional de que o magistrado irá justificar o conteúdo decisório, a partir dos argumentos fático-probatórios trazidos pelas partes durante o iter procedimental, em observância e conexão com o princípio do contraditório, a fim de que haja participação, influência e controle do conteúdo decisório.

A fundamentação, que não se confunde com motivação, foi normativamente incorporada no Código de Processo Civil, em seu artigo 489, e devidamente articulada com o princípio do contraditório como garantia de influência, e não surpresa. Referido artigo traz hipóteses em que não considera fundamentada e, consequentemente, nula, decisão que não observar o conjunto argumentativo e probatório constante dos autos.

$\bigcirc$ conteúdo de tal dispositivo não pode ser afastado estrategicamente, como têm feito os tribunais pátrios, em nome da celeridade e da incessante busca por resultados, já que reduz as partes a meros clientes e as tornam instrumentos de poder, o que não coaduna com os ditames da constitucionalidade democrática, já que o povo é sujeito constitucional ativo na construção das decisões estatais, principalmente jurisdicionais.

A ausência de fundamentação em nome da celeridade causa déficit de legitimidade e democraticidade ao processo, pois permite que a discricionariedade do julgador 
se torne motivo para decidir. Essa postura inconstitucional não permite que as partes exerçam controle e fiscalizem a atividade jurisdicional, além de olvidar a efetivação de direitos e garantias fundamentais e ferir o contraditório e a ampla defesa. Trata-se de enorme retrocesso causado à democracia e à concepção de processo como instituição constitucionalizada de implementação de direitos e garantias fundamentais assegurados constitucionalmente.

No Estado Democrático de Direito, a duração razoável do processo, a celeridade e a efetividade não são vistas como princípios instrumentais para a busca de resultados, já que devem ser harmônicos com a principiologia fundante do processo, a partir do contraditório, da ampla defesa e da isonomia.

Assim, tais princípios determinam o cumprimento dos prazos procedimentais fixados em lei, combatem dilações indevidas e permitem a eficiência quantitativa e qualitativa do sistema, a fim de se gerar legitimidade democrática.

Dessarte, a decisão de saneamento e organização surge como uma técnica e como um filtro para a fundamentação das decisões, pois irá delimitar as questões de fato e de direito, bem como as provas a serem produzidas no processo, permitindo uma adequada articulação entre fundamentação e contraditório.

Desta feita, fundamentação e celeridade tornam-se princípios compatíveis, desde que observadas as garantias do contraditório, da ampla defesa e da isonomia, além da necessidade de se levar em consideração que as etapas mortas do procedimento e a ausência de estrutura do judiciário são as causas da morosidade.

\section{REFERÊNCIAS}

ALMEIDA, Andréa Alves. Espaço jurídico processual na discursividade metalinguística. Curitiba: CRV, 2012.

ALVES, Isabella Fonseca; MUNDIM, Luís Gustavo Reis. Técnica processual e fundamentação das decisões no Código de Processo Civil de 20 I 5. Revista ESMAT, v. 9, n. 14, p. 65-82, fev. 20 I 8. Disponível em: <http://esmat.tjto.jus.br/publicacoes/ index.php/revista_esmat/article/view/209/193>. Acesso em: 9 abr. 2018.

BARROS, Flaviane de Magalhães. A fundamentação das decisões a partir do modelo constitucional de processo. In: Revista do Instituto de Hermenêutica Jurídica: 20 anos de constitucionalismo democrático - e agora?, vol. I, n. 6. Porto Alegre: Instituto de Hermenêutica Jurídica, 2008, p. |31-148.

BEDAQUE, José Roberto dos Santos. Efetividade do processo e técnica processual. 3. ed. São Paulo: Malheiros, 2010.

BRASIL. Superior Tribunal de Justiça. EDd no MS 21.315/DF, Rel. Ministra Diva Malerbi (Desembargadora Convocada do TRF $3{ }^{a}$ Região), Primeira Seção. Diário de Justiça, Brasília, I 5 jun. 2016. 
BRÊTAS, Ronaldo de Carvalho Dias. As reformas do Código de Processo Civil e - Modelo Constitucional de Processo. In: BRÊTAS, Ronaldo de Carvalho Dias. NEPOMUCENO, Luciana Diniz. Processo civil reformado. Belo Horizonte: Del Rey, 2009.

BRÊTAS, Ronaldo de Carvalho Dias. Processo Constitucional e estado democrático de direito. 3. ed., rev. e ampl. Belo Horizonte: Del Rey, 2015.

BRÊTAS, Ronaldo de Carvalho Dias et al. Estudo sistemático do NCPC. 2.ed. Belo Horizonte: D'Plácido, 2016.

CARVALHO, João Carlos Salles de. Pedagogia judicial e processo democrático: a fala processual como exercício de cidadania. Belo Horizonte: D'Plácido, 2018.

GHEDINI NETO, Armando. Técnica estrutural dos atos jurisdicionais decisórios. In: BRÊTAS, Ronaldo de Carvalho Dias. SOARES, Carlos Henrique. (Coord.). Técnica processual. Belo Horizonte: Del Rey, 2015.

HAN, Byung-Chul. Sociedade do cansaço. Trad. Enio Paulo Giachini. 2. ed. Petrópolis: Vozes, 2017.

LEAL, André Cordeiro. A inconstitucional ancianidade do (ante)projeto do novo Código de Processo Civil. In: CASTRO, João Antônio Lima. (Coord.) Direito processual. Belo Horizonte: Instituto de Educação Continuada, 2012.

LEAL, André Cordeiro. O contraditório e a fundamentação das decisões no direito processual democrático. Belo Horizonte: Mandamentos, 2002.

LEAL, Rosemiro Pereira. A Teoria Neoinstitucionalista do Processo: uma trajetória conjectural. Belo Horizonte: Arraes, 2013.

LEAL, Rosemiro Pereira. Teoria geral do processo: primeiros estudos. 13. ed. Belo Horizonte: Fórum, 2016a.

LEAL, Rosemiro Pereira. Teoria processual da decisão jurídica. 2. ed. Belo Horizonte: D'Plácido, 20 I6b.

MAGALHÃES, Joseli Lima. A fundamentação das decisões jurisdicionais e suas relações com o contraditório: da origem à presença marcante no novo CPC. In: MAGALHÃES, Joseli Lima. (coord.). O processo e os impasses da legalidade. Teresina: EDUFPI, 2018. p. 19-64.

MUNDIM, Luís Gustavo Reis. Precedentes: da vinculação à democratização. Belo Horizonte: D'Plácido, 2018. 
NUNES, Dierle. $\bigcirc$ princípio do contraditório: uma garantia de influência e não surpresa. In: TAVARES, Fernando Horta. (Coord.). Constituição, direito e processo. Curitiba: Juruá, 2007, p. |45-165.

NUNES, Dierle. TEIXEIRA, Ludmila. Acesso à justiça democrático. Brasília: Gazeta Jurídica, 2013.

NUNES, Dierle. SILVA, Natanael Lud Santos e. PEDRON, Flávio Quinaud. Desconfiando da imparcialidade dos sujeitos processuais: um estudo sobre os vieses cognitivos, a mitigação de seus efeitos e o debiasing. Salvador: JusPodivm, 2018.

SOUSA, Lorena Ribeiro de Carvalho. O dever de fundamentação das decisões no Código de Processo Civil de 2015: um estudo crítico das decisões do superior tribunal de justiça a partir do modelo constitucional de processo. Dissertação (Mestrado). Pontifícia Universidade Católica de Minas Gerais, Programa de PósGraduação em Direito. Belo Horizonte, 2018.

TAVARES, Fernando Horta. Tempo e processo. In: TAVARES, Fernando Horta. (Coord.) Urgências de tutela. Curitiba: Juruá. 2010.

THEODORO JÚNIOR, Humberto. NUNES, Dierle José Coelho. BAHIA, Alexandre Melo Franco. PEDRON, Flávio Quinaud. Novo CPC - Fundamentação e sistematização. 3. ed. rev., atual. e ampl. Rio de Janeiro: Forense, 2016.

THIBAU, Vinicius Lott. Teoria do processo democrático e técnica probatória. In: BRÊTAS, Ronaldo de Carvalho Dias. SOARES, Carlos Henrique. (Coord.). Técnica processual. Belo Horizonte: Del Rey, 2015.

VARELA, Alexandre de Oliveira. Técnica de saneamento e organização do procedimento no Código de Processo Civil de 2015. Dissertação (Mestrado). Pontifícia Universidade Católica de Minas Gerais, Programa de Pós-Graduação em Direito. Belo Horizonte, 2018.

Recebido em: 07/05/2019

Aprovado em: 05/06/2019 
